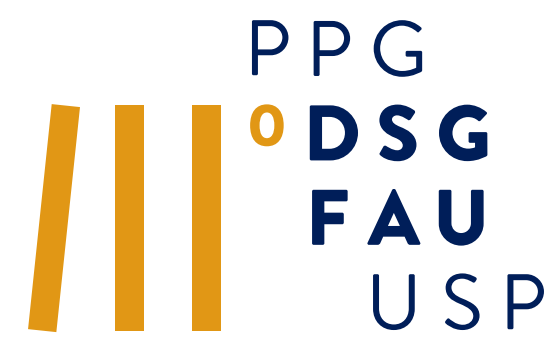

ALICE VIGGIANI

CLICE DE TOLEDO

SANJAR MAZZILLI

NÍVEL DE PESQUISA

RESEARCH LEVEL

MESTRADO

MASTER

\section{ALICE VIGGIANI}

Designer gráfica, formada em arquitetura e urbanismo pela FAU USP. Trabalhou no estúdio Warrakloureiro, revista Bamboo, Masp, Estúdio Lógos e no e-commerce Basico.com. Atualmente é mestranda do curso de design da FAU USP sob orientação da professora Dra. Clice Mazzilli e ministra o curso "Fotoensaio: revista de fotografia", junto com Ed Viggiani, pelas oficinas de criatividade do Sesc Pompeia.

Graphic designer, graduated in architecture and urbanism by FAU USP. Worked at Warrakloureiro studio, Bamboo magazine, Masp, Lógos studio and the e-commerce Basico. com. She is currently a master's student at FAU USP's design course under the guidance of Dr. Clice Mazzill and teaches the course "Fotoensaio: photography magazine", along with Ed Viggiani, by Sesc Pompeia's creativity workshops.

aliceviggiani@gmail..com

lattes.cnpq.br/

2236597148420113

\section{CLICE DE TOLEDO SANJAR MAZZILLI}

Professora Associada nos cursos de Arquitetura e Urbanismo e Design da Universidade de São Paulo. Orienta pesquisas em design gráfico e ambiental com ênfase em: narrativas visuais; design do livro; processos experimentais em design; espaços infantis.

Associate Professor of Architecture and Urbanism and Design at the University of São Paulo. Her research interests include both graphic and environmental design with emphasis on: visual narratives; book design; experimental design processes:

children's spaces.

clice@usp.br

lattes.cnpq.br/

9635315172253349

\title{
DESIGN SYSTEMS E ESTILO TIPOGRÁFICO INTERNACIONAL: PARALELOS ENTRES DOIS MOMENTOS DA HISTÓRIA DO DESIGN GRÁFICO
}

\author{
DESIGN SYSTEMS AND INTERNATIONAL TYPOGRAPHIC \\ STYLE: PARALLELS BETWEEN TWO MOMENTS IN GRAPHIC \\ DESIGN HISTORY
}

\section{PALAVRAS-CHAVE: DESIGN DIGITAL; ESTILO TIPOGRÁFICO INTERNACIONAL; GRID; SISTEMAS; PROGRAMAS}

KEYWORDS: DIGITAL DESIGN; INTERNATIONAL TYPOGRAPHIC STYLE; GRID; SYSTEMS; PROGAMMES

O design digital e, mais precisamente, o assim denominado Design System, produzido atualmente (do ano 2000 até hoje) contém em sua gênese aspectos - como racionalidade, objetividade, visão sistêmica e programática, dependência de malhas construtivas e modularidade etc. - que configuravam a base da linguagem desenvolvida pelo período das décadas de 1950 e 60 que ficou conhecido como Estilo Tipográfico Internacional, originado na Suíça e Alemanha e logo difundido para outros países. Que elementos do design moderno europeu desses anos são igualmente possíveis de serem observados no design digital contemporâneo é o que a pesquisa vai procurar percorrer. $O$ principal objetivo do trabalho é investigar que elementos são esses do ponto de vista formal e sintático do desenho e de princípios do processo criativo. $E$, mais além, procurar entender qual a raiz do pensamento moderno que permitiu tal antecipação. $O$ grid será utilizado como o principal parâmetro de comparação e análise. E, para tanto, serão estudados cânones do design gráfico moderno e sistemas de identidades emblemáticos, elencados a partir de sua íntima relação com o parâmetro definido. Alguns dos objetos de estudo serão Josef Müller-Brockmann (Suíça, 1914-96), por ter sistematizado o conhecimento sobre grelhas, e Karl Gerstner (Suíça, 1930-2017), por ter pensado de maneira ampla sobre a criação de programas para processos criativos. E pensando em sistema de identidade corporativa, 0 Material Design, do Google, serve até mesmo como base para outras identidades. "Design systems 1.0", é assim que as identidades encomendadas por grandes companhias no período moderno foram denominadas por Hidde de Vries. E é essa noção, de gênese e versão primária, o que se pretende investigar no presente trabalho.

The digital design and, more precisely, the Design System, currently developed (from the year 2000 until today) contains in its genesis aspects - such as rationality, objectivity, systemic and programmatic vision, grid dependence and modularity, etc. - which formed the basis of the style produced by the 1950s and 60s, known as International Typographic Style, born in Switzerland and Germany and spread to other countries. The research will investigate which elements of modern European design of these years are equally observable in contemporary digital design. The main objective of the work is to investigate which elements are these from the formal and syntactic point of view of the design and principles of the creative process. And, further, seek to understand the root of modern thought that has allowed such anticipation. The grid will be used as the main comparison and analysis parameter. And, for this, canons of modern graphic design and emblematic identity systems will be studied, based on their intimate relationship with the defined parameter. Some of the objects of study will be Josef MüllerBrockmann (Switzerland, 1914-96), for systematizing knowledge about grids, and Karl Gerstner (Switzerland, 1930-2017), for having thought broadly about the creation of process programs. creative. And thinking of corporate identity system, Google's Material Design even serves as the basis for other identities. "Design systems 1.0" is how the identities commissioned by large companies in the modern period were named by Hidde de Vries. And it is this notion of genesis and primary version that is intended to be investigated in the present work. 